\title{
Bibliometric analysis of sports studies in the "Journal Sport Area"
}

\author{
Yulingga Nanda Hanief \\ Universitas Negeri Malang, Indonesia \\ Received: 06 May 2021; Accepted 02 June 2021; Published 01 August 2021 \\ Ed 2021; 6(2): 263-274
}

\begin{abstract}
This study aims appreciate the Journal Sport Area for the achievement of a nationally accredited rank the $2^{\text {nd }}$ in 2020 by evaluating the publication patterns and scientific progress of the Journal Sport Area between 2016 and 2020 which includes the most productive authors, the most productive institutions, the most cited articles, the number of citations, and the level of author collaboration. This research is a qualitative descriptive study with a bibliometric analysis approach. Bibliometric analysis is used to evaluate publication patterns and scientific progress by adding data visualization with the help of the VOSViewer application from bibliographic data, coauthorship, and co-occurrence of keywords. The results of the analysis showed that the number of articles produced per year is concluded to be consistent with an average of 20.4. The most productive writer is Fadli Surahman from Universitas Karimun with 4 articles. The most productive institution is Universitas Islam Riau with 38 articles. The number of citations was 196 throughout 2017-2021. The level of collaboration of the Journal Sport Area before being accredited occurred in two types, namely publications carried out individually from 2016-2017 and collaboratively starting from 2018-2020. This study concludes that the pattern of publication and scientific progress in the Journal Sport Area has changed from year to year, which is marked by changes in the level of collaboration and an increase in the number of citations as well as the emergence of topics that have opportunities (research gaps) for further research. This research is useful for understanding questions related to scientific products such as the number of publications, contributors, keywords, countries, and institutions that are often used in journal articles. Research trends in the Journal Sport Area are learning strategies in physical education. The originality value of this study presents exclusive bibliometric analysis data and identifies the main trends of publication in journals from the beginning of its establishment in 2016 to being accredited SINTA 2 in 2020.
\end{abstract}

Keywords: Bibliometric; SINTA; journal; VOSViewer

https://doi.org/10.25299/sportarea.2021.vol6(2).6845
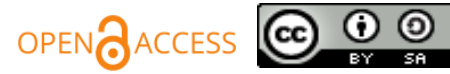

Copyright (C) 2021 Yulingga Nanda Hanief

Corresponding author: Yulingga Nanda Hanief, Department of Sport Coaching, Faculty of Sports Science, Universitas Negeri Malang, Malang, Indonesia

Email: yulingga.hanief.fik@um.ac.id

How to Cite: Hanief, Y. N. (2021). Bibliometric analysis of sports studies in the "Journal Sport Area". Journal Sport Area, 6(2), 263-274. https://doi.org/10.25299/sportarea.2021.vol6(2).6845

\section{INTRODUCTION}

Sport is a field of science that continues to grow, starts from the academic and non-academic fields. In the academic field, one of them is marked by the productivity of scientific publications. In Spain, students who earn a doctorate in sports contribute significantly to the production of scientific publications (HernándezGonzález et al., 2020). Meanwhile in Indonesia, undergraduate, masters, and doctoral students are required to publish scientific publications as stated in Circular No. 152/E/T/2012 dated January 27, 2012 which 
certainly has an impact on increasing the productivity of scientific publications. We should welcome this progress with the spirit of conducting quality research.

Every year, universities in Indonesia graduate hundreds of students in the field of sports, of course, students can complete their studies by conducting research and publications. Estuary publications can be published in proceedings or journals. When referring to Circular No. 152/E/T/2012 dated January 27, 2012, students were directed to publish articles in scientific journals. Data for scientific journals in the Science and Technology Index (SINTA) on May 6, 2021, there are 5,531 journals that have been accredited by SINTA (https://sinta.ristekbrin.go.id/journals) spread from rank 1 to rank 6 (small numbers indicate the highest level).

The increase in scientific publications in journals must of course also be balanced with control over the quality and quantity of published articles. Several studies that conducted an analysis of journals, including Rahayu and Idhani (2019) reported a bibliometric analysis of the journal "Khizanah al-Hikmah: Jurnal Ilmu Perpustakaan, Informasi, dan Kearsipan", a journal published by the Universitas Islam Negeri Alauddin Makassar. The analysis includes the number of published articles, article writing patterns, references used by published articles, productive authors, and productive institutions. Likewise, Royani and Idhani (2019) who also analyzed bibliometrically the Journal of Marine Research in Indonesia, Saleh and Sumarni (2019)a analyzed the Standardization Journal, and Muhajan (2011) who analyzed the Journal of Animal and Veterinary Science. While in the field of sports in Indonesia, there is only one research that evaluates an accredited national journal. Hanief (2021a) analyzed "Jurnal SPORTIF: Jurnal Penelitian Pembelajaran". The findings show that one of the editors has the highest number of documents from all publications and Universitas Nusantara PGRI Kediri as the publisher is also the institution that contributes the most manuscripts.

In this study, the authors attempt to analyze the Journal Sport Area, published by the Universitas Islam Riau. This analysis was carried out as a form of congratulations to the editorial team who succeeded in delivering the SINTA 2 accredited Journal Sport Area at the end of 2020 referring to the Decree of the Minister of Research and Technology/Head of the National Research and Innovation Agency Number 200/M/KPT/2020 concerning the Accreditation Rating of Scientific Journals. Period III 2020, the analysis carried out was to evaluate the publication pattern and scientific progress of the Journal Sport Area between 2016 and 2020 which included the most productive authors, the most productive institutions, the most cited articles, the number of citations, and the degree of collaboration of the authors. The publications analyzed are from 2016 to 2020. The analysis is carried out using bibliometric analysis which includes the most productive authors, the most productive institutions, the most cited articles, the number of citations, the level of collaboration of the authors. In addition, with the help of the VOSViewer application, the authors analyze the joint occurrence of keywords (co-occurrence) and co-authorship which is realized in the form of data visualization.

This study is important to do to maintain the quality and quantity of publications in the Journal Sport Area, considering that the journal is also one of the sports journals that it is a reference in Indonesia. Journal Sport Area is also undergoing a new round at SINTA 2 ranking. Therefore it is expected that in the future it will be more selective with submissions. Bibliometric analysis is used to analyze statistically including the number of published articles, productivity, number of citations, and indicators that measure the impact of the articles produced (Devos, 2011). From the statistical analysis, it will be concluded with a qualitative approach regarding the quality of a journal, including evaluating whether the journal publishes articles outside its scope, whether the most productive authors are produced by the editors of the Journal Sport Area, and what publication themes are trending in the Journal Sport Area. Several bibliometric studies related to journals have been carried out (Albort-Morant \& Ribeiro-Soriano, 2016; Natakusumah, 2016; Rahayu \& Tupan, 2020; Royani \& Idhani, 2019), however, only one bibliometric analysis of sports journals in Indonesia has ever been carried out (Hanief, 2021a). This study presents exclusive bibliometric analysis data and identifies the main trends of publication in the Journal Sport Area from its inception in 2016 to being declared SINTA 2 accredited in 2020. The most interesting thing about this study with other studies, the 
authors also attempt to discuss and suggest the recruitment of reviewers, editor, suitability of reviewers who have been assigned, and revision of journal coverage based on the bibliometric analysis.

\section{METHOD}

Bibliometric indicators are used to evaluate bibliographic data, including the number of authors and articles, citations, and institutions. In addition, the documents used for the analysis are obtained from the Journal Sport Area page (https://journal.uir.ac.id/index.php/JSP). The author uses the Mendeley application on the Archive menu to download all metadata of articles published from 2016 to 2020, because the Journal Sport Area was declared accredited in December 2020, so the author only wants to analyze publications before 2020. In addition to the number of authors, the number of articles, citations, and institutions, the authors also analyzed the co-occurrence of keywords, overlay visualization, and co-authorship. The analytical structure used in this study is in line with several bibliometric studies conducted on other topics (Verma \& Gustafsson, 2020). The number of articles obtained was 102 articles published from 2016 to 2020. These documents were further analyzed with the VOSViewer application. The design of this study is presented in Figure 1.

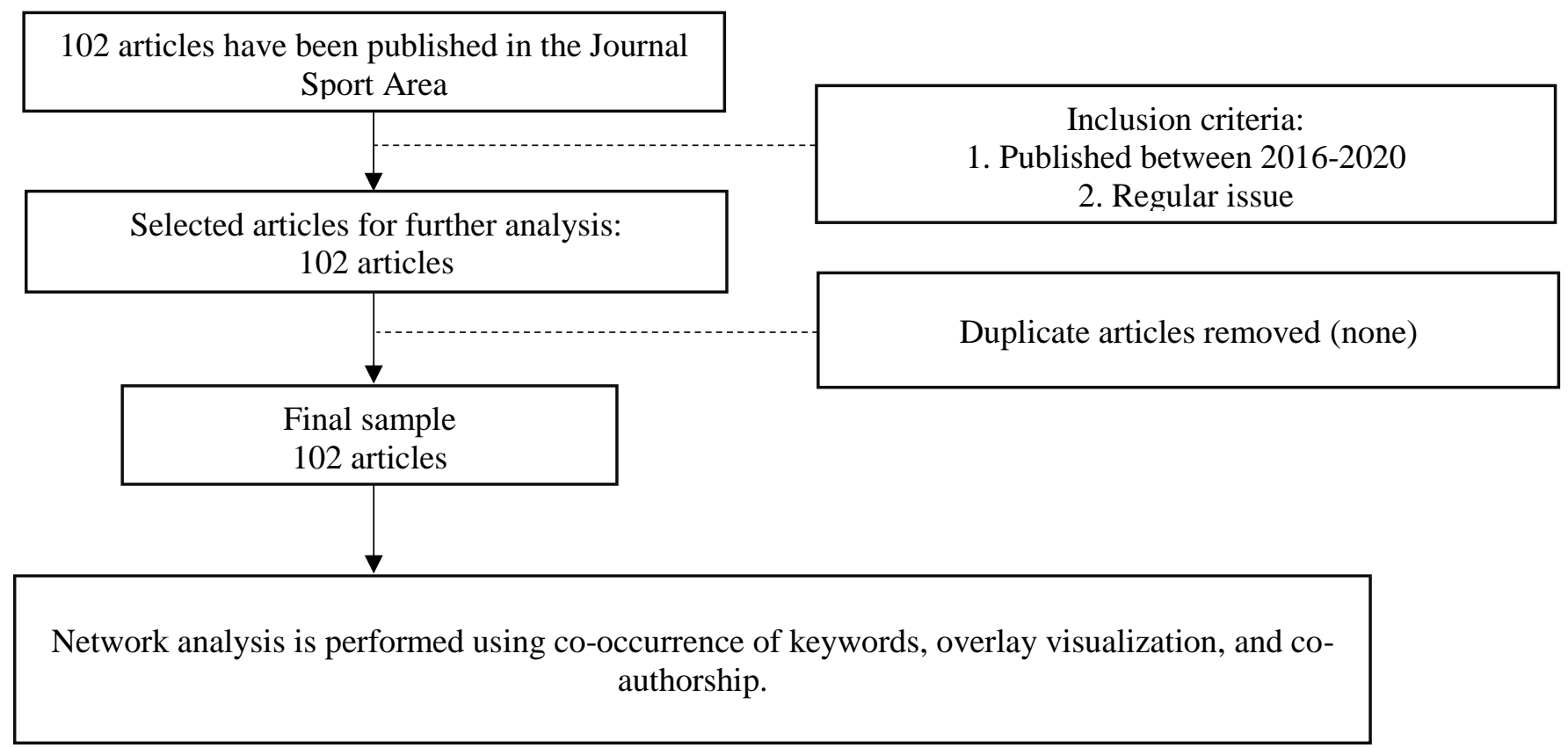

Figure 1. Design of Study

Collecting data by tracing each issue from volume 1 number 1 of 2016 to volume 5 number 2 of 2020 . The author uses the Mendeley application to get the metadata of all articles. The author checks the completeness of the metadata of each article on the Mendeley Desktop. There are several articles whose metadata is incomplete, so the researcher tries to complete it.

The bibliographic data were mapped graphically using the VOSviewer application to further explain the results (van Eck \& Waltman, 2010). The results of the analysis (analysis output) from the application are network analyzes, co-authorship, and co-occurrence (Martínez-López et al., 2018). The level of collaboration is calculated using the Subramanyam (1983), formula, namely:

$C=\frac{N_{m}}{N_{m}+N_{s}}$ 
Where:

$\mathrm{C}=$ collaboration degree

$\mathrm{Nm}=$ the overall results of research conducted in collaboration

Ns = overall results of research conducted individually

Note, if:

a. Score $\mathrm{C}=0$, it can be concluded that the results of the research were all carried out individually

b. Score $\mathrm{C}=0<\mathrm{C}<0.5$, it can be concluded that the results of research conducted individually are greater than those carried out in collaboration

c. A score of $\mathrm{C}=0.5$ means that there are as many individual studies as those conducted in collaboration

d. Score $\mathrm{C}=0.5<\mathrm{C}<1$, it can be concluded that the results of research conducted in collaboration are more than those carried out individually

\section{RESULT AND DISCUSSION}

\section{Number of Publications and Citations}

The search results with the help of the Mendeley application obtain 102 articles that have been published starting from volume 1 number 1 in 2016 to volume 5 number 2 in 2020 . The distribution of articles in each issue can be shown in Figure 2 below.

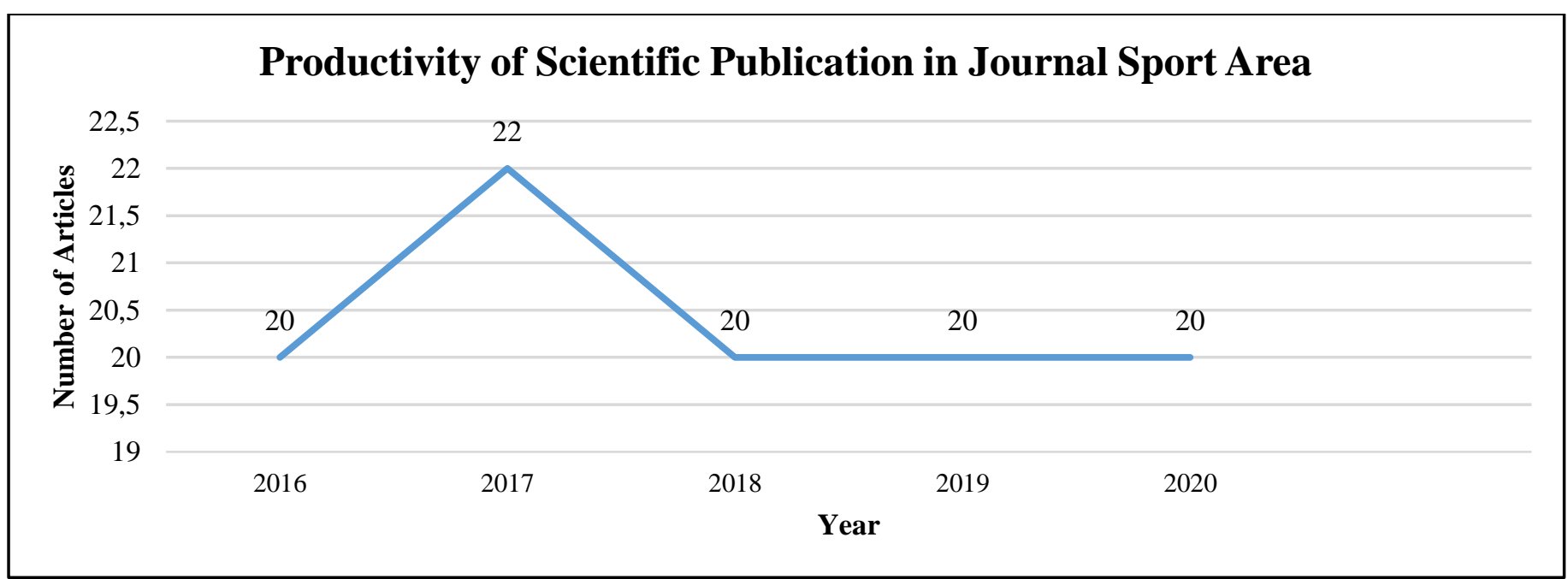

Figure 2. Number of articles published in the Journal Sport Area from 2016 to 2020

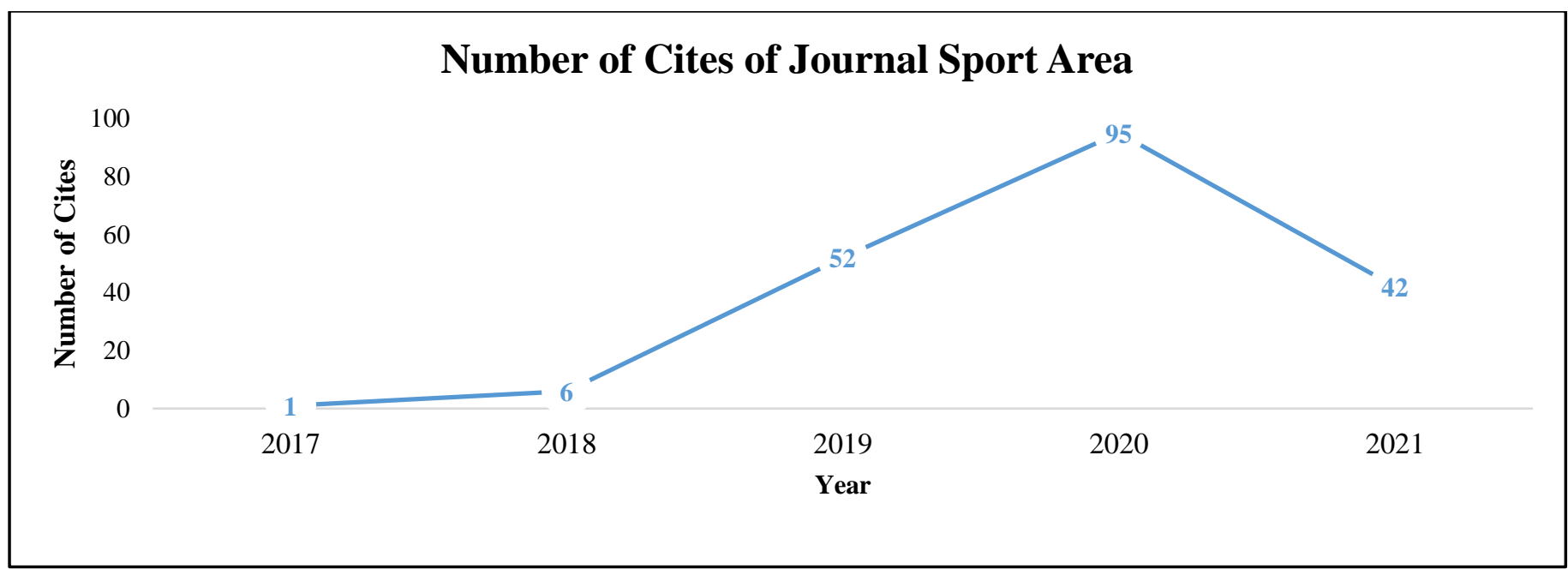

Figure 3. Number of Cites for 2017-2021 
Figure 3 shows the number of citations from 2017-2020 as many as 196 citations. An article published in 2016 has never been cited by another article in 2016. So as of 2016, the Journal Sport Area does not have a citation count. There has been an increase in the number of citations from 2018 to 2020 and there is still a chance to increase the number of citations in 2021 considering that 2021 is not over yet.

Referring to Figure 2, it can be seen that the number of articles published each year can be concluded to be consistent with an average of 20.4 articles published each year, although in 2017 there was a not very significant increase. The search results also obtained the top 6 most cited articles, which are shown in Table 1 below.

Table 1. Top 6 Most Cited Articles

\begin{tabular}{|c|c|c|c|c|}
\hline Ranking & $\begin{array}{c}\text { Number of } \\
\text { Citation } \\
\end{array}$ & Article Titles & Authors & $\begin{array}{c}\text { Publication } \\
\text { Year } \\
\end{array}$ \\
\hline 1 & 11 & $\begin{array}{l}\text { Pengaruh metode kooperatif dan komando terhadap } \\
\text { keterampilan teknik dasar bermain sepakbola }\end{array}$ & Novri Gazali & 2016 \\
\hline 2 & 10 & $\begin{array}{l}\text { Hubungan kelincahan dengan keterampilan } \\
\text { menggiring bola basket mahasiswa baru program } \\
\text { studi pendidikan olahraga STKIP PGRI Bangkalan }\end{array}$ & Fajar Hidayatullah & 2018 \\
\hline 3 & 9 & $\begin{array}{l}\text { Pengaruh latihan menendang menggunakan imageri } \\
\text { terhadap akurasi tendangan ke gawang }\end{array}$ & Alfi Candra & 2016 \\
\hline 4 & 7 & $\begin{array}{l}\text { Pengembangan buku ajar mata kuliah renang bagi } \\
\text { mahasiswa pendidikan jasmani kesehatan dan } \\
\text { rekreasi }\end{array}$ & $\begin{array}{l}\text { Fadli Surahman, } \\
\text { Hilda Oktri Yeni }\end{array}$ & 2019 \\
\hline 5 & 7 & $\begin{array}{l}\text { Pengaruh latihan pukulan menggunakan imagery } \\
\text { terhadap hasil smash permainan bola voli Tim Putra } \\
\text { Penjaskesrek Universitas Islam Riau Pekanbaru }\end{array}$ & $\begin{array}{l}\text { Alfi Candra, } \\
\text { Raffly Henjilito }\end{array}$ & 2018 \\
\hline 6 & 7 & $\begin{array}{l}\text { Pengembangan sumber daya manusia keolahragaan } \\
\text { (survei manajemen sumber daya manusia } \\
\text { keolahragaan Kabupaten Tapanuli Selatan Tahun } \\
\text { 2012) }\end{array}$ & Toktong Parulian & 2016 \\
\hline
\end{tabular}

Referring to Table 1, it can be seen that the most cited article with a total of 11 citations was written by Gazali (2016) with the title "Pengaruh Metode Kooperatif dan Komando Terhadap Keterampilan Teknik Dasar Bermain Sepakbola". The number of citations is important for the reputation of a journal, because the impact of the journal on scientific development can be measured by the number of citations (Di Bitetti \& Ferreras, 2017). The number of citations is also an indicator of the quality of an article, so journal managers need to pay attention to the factors that influence citations in the manuscript (Bai et al., 2019). This means that the journal manager must conduct a desk review at an early stage whether the submitted manuscript has the potential to be quoted by other articles after the manuscript is published online. This obviously cannot be separated from the basic scope (focus and scope) of the journal.

There are several previous studies that have focused on citation prediction or analysis of future citation distributions. Several studies have used machine learning algorithms such as Gradient Boosting Decision Tree (Sandulescu \& Chiru, 2016), Support Vector Machine (Adankon et al., 2009), and XGBoost (Chen \& Guestrin, 2016). Several citation prediction studies have applied generative models to reflect the observation that articles published longer usually receive higher citations (Newman, 2009), these studies also confirm the findings of this study that the highest citations are obtained by articles published in volume 1 number 1 year 2016 written by Gazali (2016).

Studies on physical education are indeed trending in recent years. Referring to Hanief (2021), his study describes the trend of scientific publications in the field of physical education in international journals indexed by Scopus. His findings explained that the theme of "physical education" experienced a trend in early 2017. This means that studies on physical education are not only popular in the Journal Sport Area but also at the international level.

The author also comes across one article that is outside the scope of the Journal Sport Area. The article was published in volume 1 number 2 of 2016 written by Ahmad (2017) with the title "Pendidikan 
Kemandirian Dalam islam". This is also an evaluation material for the editorial team to be more stringent in selecting articles at an early stage. However, this finding occurred only once and not repeatedly, it means that there are several factors and considerations why the article is published.

The author also analyzes the cite score to emphasize that the number of citations is an indicator of the quality of an article and journal. Cite score is obtained by dividing the number of citations in the last 3 years by the number of documents in the last 3 years (James et al., 2018). The journals analyzed are journals that have been nationally accredited by SINTA 2. In 2021, the number of journals in the field of sports that have been accredited to SINTA 2 is 4 journals. The cite score data can be seen in Table 2.

Table 2. Sports Journals Accredited by SINTA 2 in Indonesia

\begin{tabular}{|c|c|c|c|c|}
\hline Ranking & Journal Name & $\begin{array}{c}\text { Number of } \\
\text { Cites }\end{array}$ & $\begin{array}{l}\text { Number of } \\
\text { Documents }\end{array}$ & $\begin{array}{c}\text { Cite score in } \\
\mathbf{2 0 2 0} \\
\end{array}$ \\
\hline 1 & Jurnal Keolahragaan & 561 & 61 & 9,20 \\
\hline 2 & Jurnal SPORTIF: Jurnal Penelitian Pembelajaran & 440 & 105 & 4,19 \\
\hline 3 & Jurnal Pendidikan Jasmani dan Olahraga & 281 & 98 & 2,87 \\
\hline 4 & Journal Sport Area & 148 & 94 & 1,57 \\
\hline
\end{tabular}

Referring to the cite score results in Table 2, it can be seen that the Sports Journal has the highest score than other journals and at the same time confirms its quality in terms of publishing scientific papers.

\section{Most Productive Writers and Institutions}

In this section, the most prolific authors and institutions have been analyzed. The list of the most prolific writers can be seen in Table 3. Fadli Surahman from Universitas Karimun, Widiastuti from Universitas Negeri Jakarta, and M. Fransazeli Makorohim from Universitas Islam Riau are the most prolific writers with a total of 4 articles.

Table 4 presents the top 10 most productive institutions. Universitas Islam Riau is the most productive institution with a total of 38 documents. This data is of particular concern considering that the publisher of the journal is the Universitas Islam Riau. Institutional diversity (diversity of affiliation) or what can be called the Author Affiliation Index (AAI) is one method to measure the quality of a journal (Ferratt et al., 2007). These criteria are first proposed by Harless and Reilly (1998). The idea behind AAI is straightforward, born of the need to be objective and practical. Instead of measuring output quality, AAI measures input quality. It assumes that the quality of the journal is determined by the quality of its articles and that the quality of the articles is correlated with the quality of the institution (academic) to which the article author is affiliated (Ferratt et al., 2007).

Table 3. Top 10 Most Productive Writers

\begin{tabular}{clcc}
\hline Rank & Authors & Affiliate & $\begin{array}{c}\text { Amount of } \\
\text { Articles }\end{array}$ \\
\hline 1 & Fadli Surahman & Universitas Karimun & 4 \\
\hline 2 & Widiastuti & Universitas Negeri Jakarta & 4 \\
\hline 3 & M Fransazeli Makorohim & Universitas Islam Riau & 4 \\
\hline 4 & Rezki & Universitas Islam Riau & 3 \\
\hline 5 & Daharis & Universitas Islam Riau & 3 \\
\hline 6 & Dupri & Universitas Islam Riau & 3 \\
\hline 7 & Novri Gazali & Universitas Islam Riau & 3 \\
\hline 8 & Raffly Henjilito & Universitas Islam Riau & 3 \\
\hline 9 & Agus Sulastio & Universitas Islam Riau & 3 \\
\hline 10 & Rices Jatra & Universitas Islam Riau \\
\hline
\end{tabular}


Table 4. Top 10 Most Productive Institutions

\begin{tabular}{|c|c|c|c|c|c|c|c|}
\hline \multirow{2}{*}{ No } & \multirow{2}{*}{ Institutions } & \multicolumn{5}{|c|}{ Year } & \multirow{2}{*}{ Amount } \\
\hline & & 2016 & 2017 & 2018 & 2019 & 2020 & \\
\hline 1 & Universitas Islam Riau & 17 & 9 & 6 & 3 & 3 & 38 \\
\hline 2 & Universitas Negeri Jakarta & & & 4 & 4 & & 8 \\
\hline 3 & Universitas Riau & 2 & & & 2 & 2 & 6 \\
\hline 4 & Universitas Siliwangi & & 5 & 1 & & & 6 \\
\hline 5 & Universitas Karimun & & & 1 & 1 & 2 & 4 \\
\hline 6 & $\begin{array}{l}\text { Universitas PGRI Adi Buana } \\
\text { Surabaya }\end{array}$ & & & 1 & 1 & 1 & 3 \\
\hline 7 & Universitas Bina Darma & & 1 & & 1 & 1 & 3 \\
\hline 8 & IKIP Budi Utomo Malang & & & & 2 & 1 & 3 \\
\hline 9 & Universitas Negeri Surabaya & & & & 1 & 2 & 3 \\
\hline \multirow[t]{2}{*}{10} & Universitas Subang & & 1 & & 1 & & 2 \\
\hline & & 19 & 16 & 13 & 16 & 12 & 76 \\
\hline
\end{tabular}

This study also analyzes the authorship (co-authorship). The analysis aims to find the interrelationships of various studies based on articles published by the authors (Figure 4). In Figure 4 there are 4 color nodes, namely blue, green, red, and yellow. Each color indicates collaboration between authors, for example, a blue node means that the authors on behalf of Muspita, Kamarudin, and Ricky Fernando are collaborating authors on an article published in the Journal Sports Area, as well as for other colors. Co-authorship networks are also a tool to investigate the direction of collaboration and identify researchers and their institutions who are leading research (e Fonseca et al., 2016), co-authorship network analysis helps solve problems and contribute to the development of knowledge (e Fonseca et al., 2016).

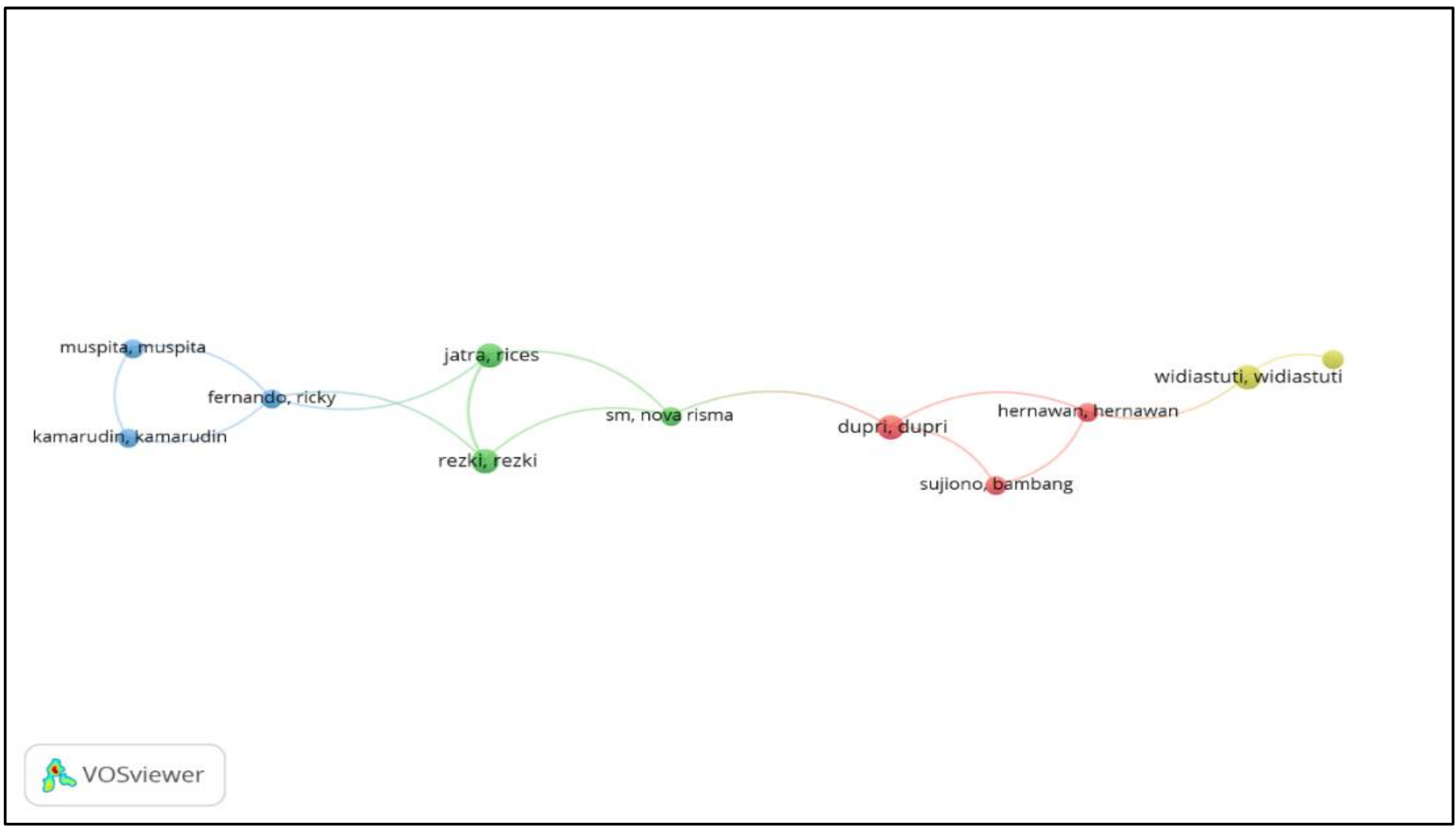

Figure 4. Co-authorship Analysis 
The level of collaboration in journals is also evaluated and the data results can be seen in Table 5 below.

Table 5. Authorship Pattern and Collaboration Level

\begin{tabular}{cccccccc}
\hline Volume/Year & 1 Author & 2 Authors & 3 Authors & 4 Authors & 5 Authors & $\begin{array}{c}\text { More than 5 } \\
\text { Authors }\end{array}$ & $\begin{array}{c}\text { Degree of } \\
\text { Collaboration }\end{array}$ \\
\hline $1 / 2016$ & 17 & 2 & 1 & - & - & - & 0,15 \\
\hline $2 / 2017$ & 16 & 6 & - & - & - & - & 0,27 \\
\hline $3 / 2018$ & 8 & 5 & 5 & 2 & - & - & 1 \\
\hline $4 / 2019$ & 3 & 5 & 7 & 4 & 1 & 1 & 0,6 \\
\hline $5 / 2020$ & 2 & 3 & 12 & 1 & $\mathbf{2}$ & 0,9 \\
\hline Amount & $\mathbf{4 6}$ & $\mathbf{2 1}$ & $\mathbf{2 5}$ & $\mathbf{7}$ & $\mathbf{1}$ & $\mathbf{0 , 5 5}$ \\
\hline Percentage (\%) & $\mathbf{4 5 , 1}$ & $\mathbf{2 0 , 5 9}$ & $\mathbf{2 4 , 5 1}$ & $\mathbf{6 , 8 6}$ & $\mathbf{0 , 9 8}$ & $\mathbf{1 , 9 6}$ \\
\hline
\end{tabular}

Based on Table 5, referring to the Subramanyam (1983) it can be concluded that publications were carried out collaboratively from 2018 to 2020 (C value > 0.5), whereas before 2018 publications were carried out individually $(\mathrm{C}$ value $<0.5)$. This change in authorship pattern was not analyzed further by the authors, but the status of the DOAJ indexed Journal Sport Area is also one of the reasons why the authors publish their manuscripts. DOAJ is an index base that provides open access journals (Irawan et al., 2018), it means that content in DOAJ indexed journals can be downloaded for free. The hope is that when the author publishes in a DOAJ indexed journal, his articles can be downloaded and read by many readers.

\section{Co-occurrence Keywords}

The author analyzed with the co-occurrence analysis type of keywords, with the full counting method, the minimum number of co-occurrence of keywords set to 1 obtained 81 keywords. The co-occurrence analysis of keywords serves to show the frequency of words arranged in articles (Gaviria-Marin et al., 2018). The search results obtained 81 keywords which were then excluded based on the suitability of the keywords with the scope of the journal so that 60 relevant keywords were obtained. The co-occurrence data of keywords is shown by visualization which can be seen in Figure 5.

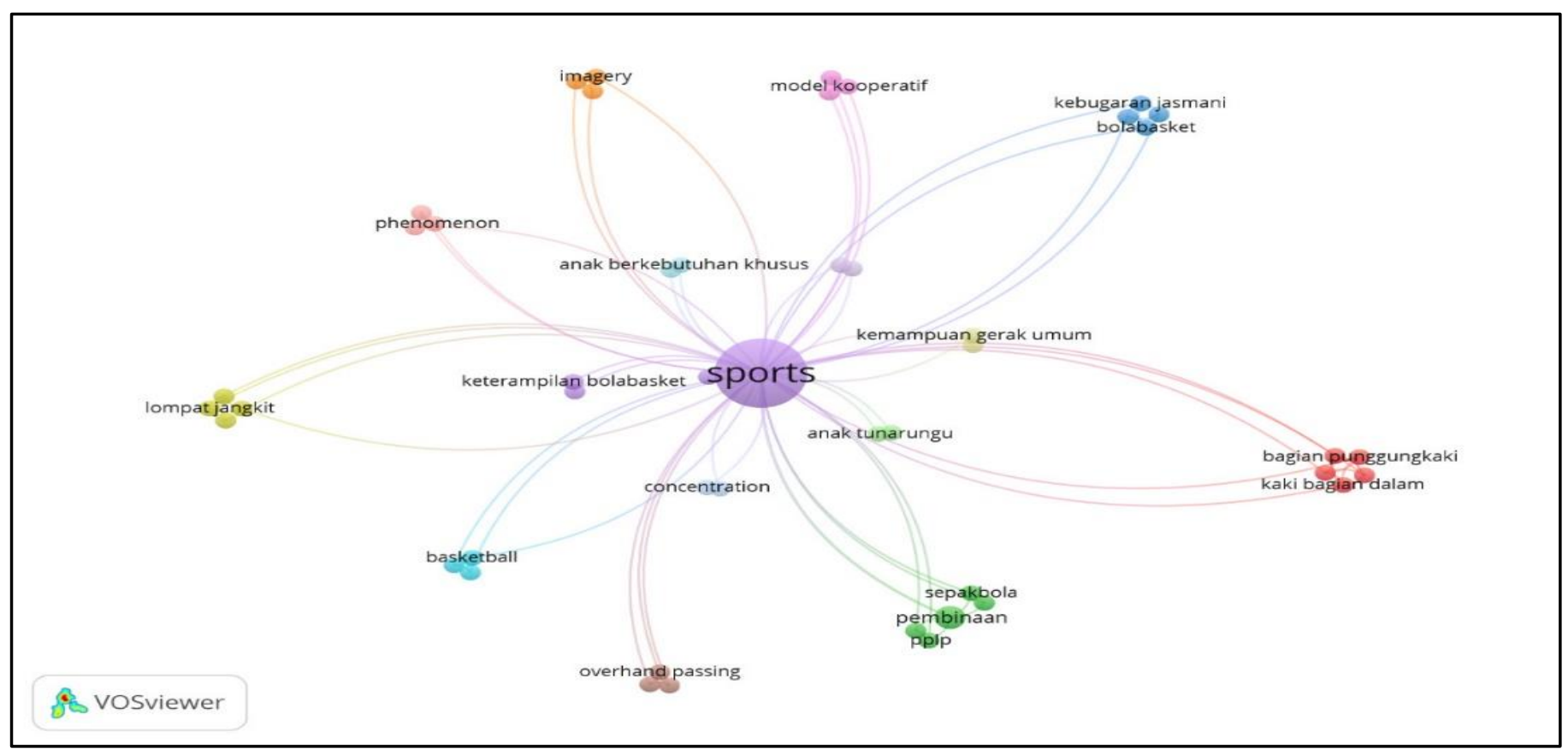

Figure 5. Network Visualization of Co-occurrence of Keywords

Figure 5 is used to find out which keywords often appear based on the size of the circle. Based on the analysis of co-occurrence (keyword co-occurrence) in Figure 5, it can be seen that the most frequently occurring keywords are "sports", "coaching", and "the back of the foot". 
"Sports" has become the top 60 most common influential keywords in the Journal Sport Area in the last 5 years. The logical reason behind this is because the term "sports" is a central topic related to almost all research in the field of sports.

VOSviewer also presents an overlay visualization of the current trend of discussion with the yellow net in Figure 6 which shows the discussion about "concentration", and "overhand passing" which is the emerging keyword in 2019. This means that there is an opportunity and need for further research on the topic.

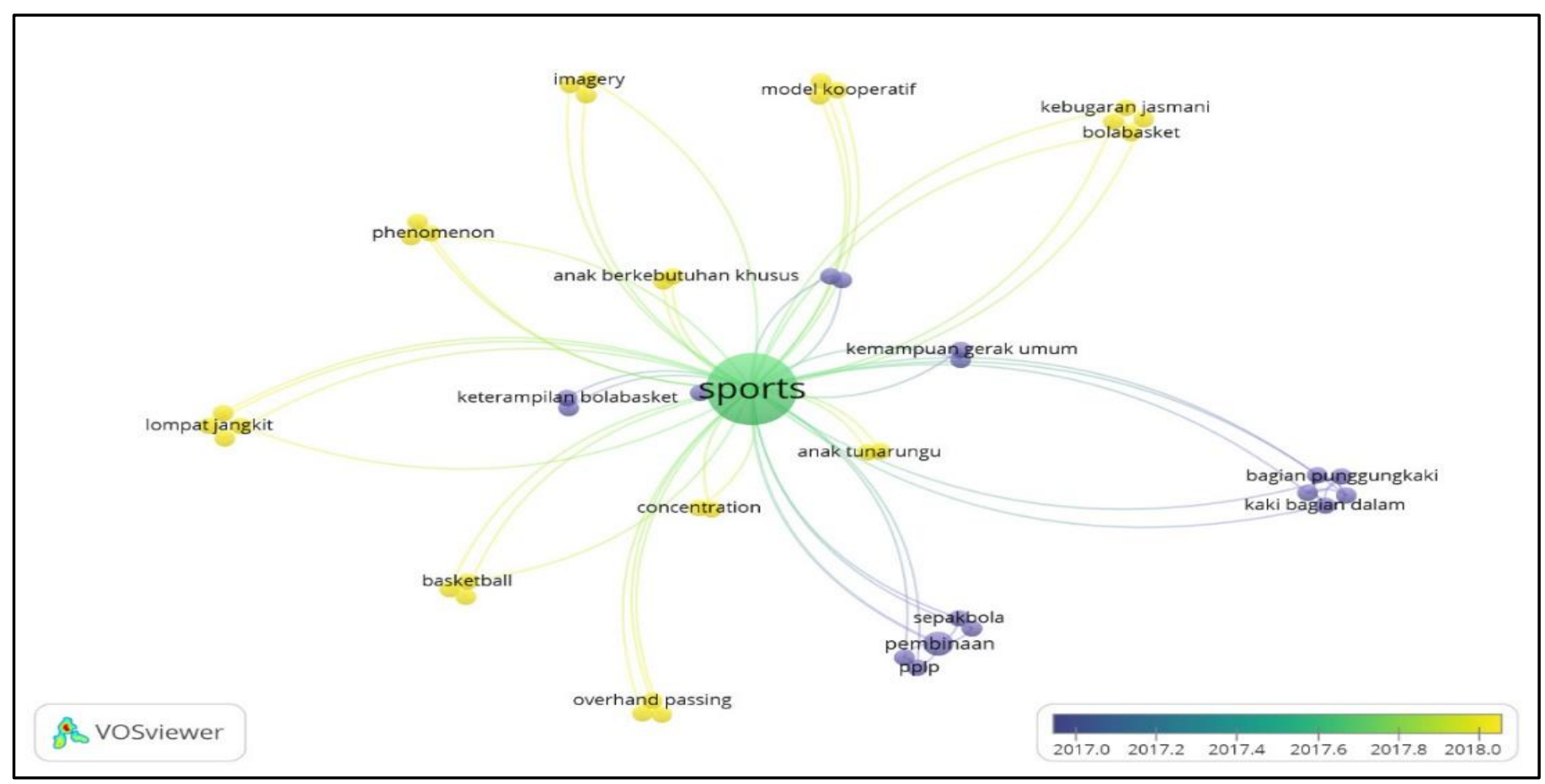

Figure 6. Overlay Visualization from Co-occurrence of Keywords

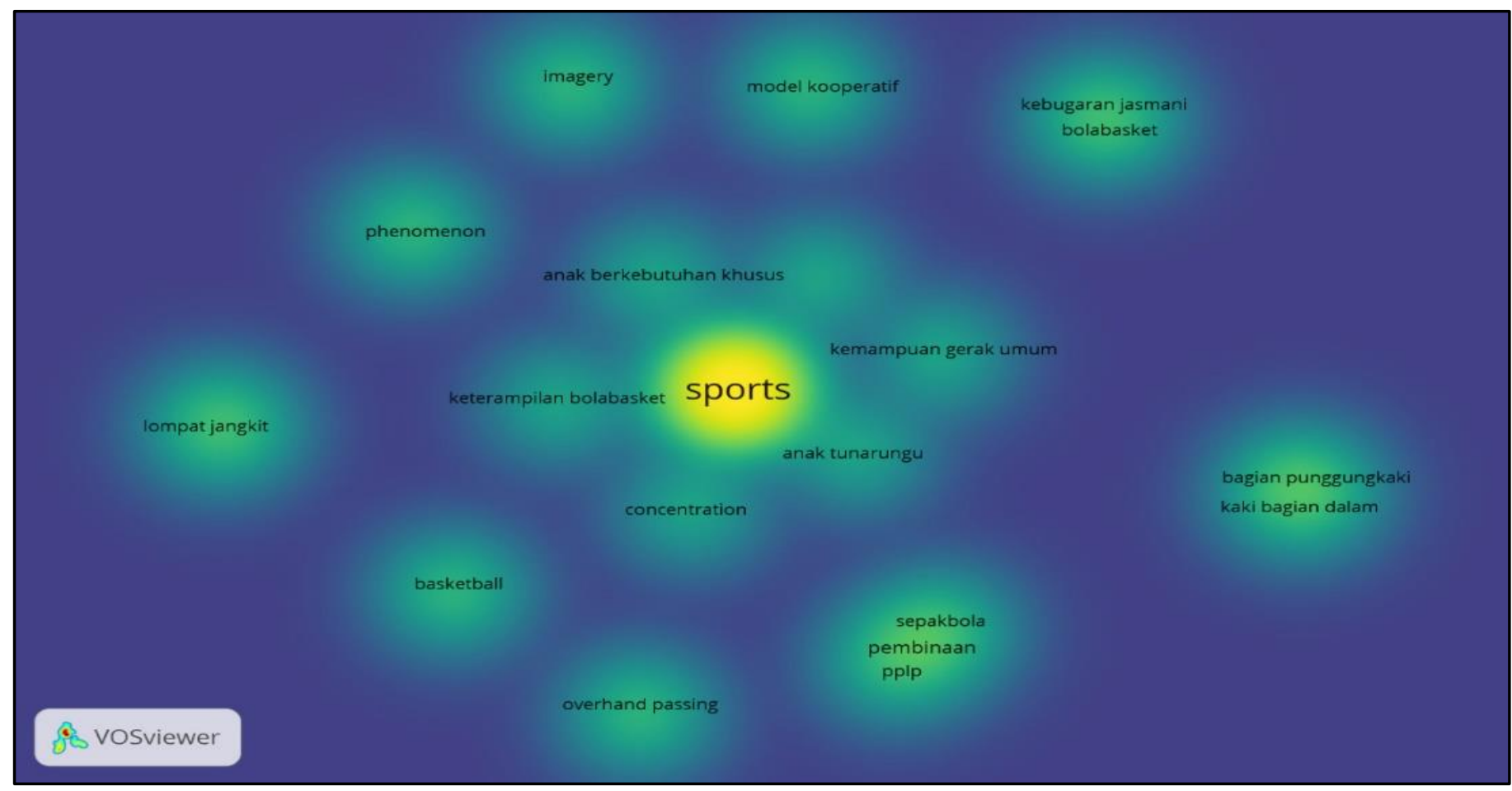

Figure 7. Density Visualization from Co-occurrence of Keywords 
Figure 7 is a density visualization of keywords that appears together and also describes the number of nodes that are close together (Aribowo, 2019). The yellow nodes indicate the level of saturation, which indicates that the number of keywords that appear frequently. The keyword "sports" is in the yellow node which is the keyword that appears most often, in other words this area is the most researched topic in the Journal Sport Area. It is different with the topics that are in the green nodes such as: "general movement skills", "children with special needs", "triple jump", "concentration", and "deaf children". Topics that are in green nodes indicate that the topic has not been studied much. This is a research gap that has the opportunity to be investigated.

In addition, the topics that often appear, which are marked by the size of the yellow node, are also input for the editor to re-analyze whether these topics are in accordance with the scientific field of the reviewer who has been assigned. If the suitability of each reviewer's field of science is not appropriate, the results of the review will also not be optimal, especially in terms of substance. The emergence of these topics is also an evaluation material for editors to narrow the scope of the journal so that the scope of the journal is more specific. This density visualization also becomes the basis for editors to recruit Editors and Reviewers whose scientific fields are in accordance with the topics that appear in Figure 7. Referring to the 2018 Scientific Journal Accreditation Manual, journals with the most specific or super specialist scope will get the highest score in the process of applying for national accreditation (Kemenristekdikti, 2018).

\section{CONCLUSION}

The Journal Sport Area has published 5 volumes from 2016 to 2020 with a total of 102 articles. The findings in this study indicate that the most productive writer is Fadli Surahman, the most productive institution is the Universitas Islam Riau, the level of collaboration in groups begins in the 2018 issue, the number of citations is 196 from 2017 to 2021, and the trending themes according to citation data is a learning strategy in physical education and according to co-occurrence the keyword is "sports".

\section{REFERENCES}

Adankon, M. M., Cheriet, M., \& Biem, A. (2009). Semisupervised least squares support vector machine. IEEE Transactions on Neural Networks, 20(12), 1858-1870. https://doi.org/10.1109/TNN.2009.2031143

Ahmad, S. (2017). Pendidikan Kemandirian Dalam Islam. Journal Sport Area, 1(2), 59-67. https://doi.org/10.25299/sportarea.2016.vol1(2).391

Albort-Morant, G., \& Ribeiro-Soriano, D. (2016). A bibliometric analysis of international impact of business incubators. Journal of Business Research, 69(5), 1775-1779. https://doi.org/10.1016/j.jbusres.2015.10.054

Aribowo, E. K. (2019). Analisis bibliometrik berkala ilmiah names: Journal of Onomastics dan peluang riset onomastik di Indonesia. Jurnal Aksara, 31(1), 91-111.

Bai, X., Zhang, F., \& Lee, I. (2019). Predicting the citations of scholarly paper. Journal of Informetrics, 13(1), 407-418. https://doi.org/10.1016/j.joi.2019.01.010

Chen, T., \& Guestrin, C. (2016). Xgboost: A scalable tree boosting system. Proceedings of the 22nd Acm Sigkdd International Conference on Knowledge Discovery and Data Mining, 785-794. https://doi.org/10.1145/2939672.2939785

Devos, P. (2011). Research and bibliometrics: a long history.... Clinics and Research in Hepatology and Gastroenterology, 35(5), 336-337. https://doi.org/10.1016/j.clinre.2011.04.008 
Di Bitetti, M. S., \& Ferreras, J. A. (2017). Publish (in English) or perish: The effect on citation rate of using languages other than English in scientific publications. Ambio, 46(1), 121-127. https://doi.org/10.1007/s13280-016-0820-7

e Fonseca, B. de P. F., Sampaio, R. B., de Araújo Fonseca, M. V., \& Zicker, F. (2016). Co-authorship network analysis in health research: method and potential use. Health Research Policy and Systems, 14(1), 1-10.

Ferratt, T. W., Gorman, M. F., Kanet, J. J., \& Salisbury, W. D. (2007). IS journal quality assessment using the author affiliation index. Communications of the Association for Information Systems, 19(1), 34.

Gaviria-Marin, M., Merigo, J. M., \& Popa, S. (2018). Twenty years of the Journal of Knowledge Management: A bibliometric analysis. Journal of Knowledge Management, 22(8), 1655-1687.

Gazali, N. (2016). Pengaruh Metode Kooperatif dan Komando Terhadap Keterampilan Teknik Dasar Bermain Sepakbola. Journal Sport Area, 1(1), 56-62. https://doi.org/10.25299/sportarea.2016.vol1(1).373

Hanief, Y. N. (2021a). Bibliometric analysis of jurnal SPORTIF: jurnal penelitian pembelajaran. Jurnal SPORTIF: Jurnal Penelitian Pembelajaran, 7(1), 51-70. https://doi.org/10.29407/js_unpgri.v7i1.15680

Hanief, Y. N. (2021b). Development of Indonesia Scientific Publications of Physical Education in Reputable International Journals: A Bibliometric Analysis. Jurnal Pendidikan Jasmani dan Olahraga, 6(1), 5967. https://doi.org/10.17509/jpjo.v6i1.32335

Harless, D., \& Reilly, R. (1998). Revision of the journal list for doctoral designation. Unpublished Report, Virginia Commonwealth University, Richmond, VA.

Hernández-González, V., De Pano-Rodríguez, A., \& Reverter-Masia, J. (2020). Spanish doctoral theses in physical activity and sports sciences and authors' scientific publications (LUSTRUM 2013-2017). Scientometrics, 122(1), 661-679. https://doi.org/10.1007/s11192-019-03295-6

Irawan, D. E., Abraham, J., Multazam, M. T., Rachmi, C. N., Mulyaningsih, I., Viridi, S., Mukti, R. R., Djamal, M., \& Puradimaja, D. J. (2018). Era baru publikasi di Indonesia: status jurnal open access di Directory of Open Access Journal (DOAJ). Berkala Ilmu Perpustakaan Dan Informasi, 14(2), 133147. https://doi.org/10.22146/bip.32920

James, C., Colledge, L., Meester, W., Azoulay, N., \& Plume, A. (2018). CiteScore metrics: Creating journal metrics from the Scopus citation index. Learned Publishing, 32(4), 367-374. http://arxiv.org/abs/1812.06871

Kemenristekdikti. (2018). Pedoman Akreditasi Jurnal Ilmiah 2018 (Cetakan Pertama). Direktorat Jenderal Penguatan Riset dan Pengembangan Kementerian Riset, Teknologi, dan Pendidikan Tinggi.

Martínez-López, F. J., Merigó, J. M., Valenzuela-Fernández, L., \& Nicolás, C. (2018). Fifty years of the European Journal of Marketing: a bibliometric analysis. European Journal of Marketing. 52(2), 439468.

Muhajan, Z. (2011). Analisis sitiran jurnal pada artikel peneliti Bbalitvet dalam Jurnal Ilmu Ternak dan Veteriner. Jurnal Perpustakaan Pertanian, 20(2), 45-53. 
Natakusumah, E. K. (2016). Bibliometric Analysis of the Inkom Journal (Analisis Bibliometrik Jurnal Inkom). JURNAL DOKUMENTASI DAN INFORMASI, 36(1), 1-10.

Newman, M. E. J. (2009). The first-mover advantage in scientific publication. EPL (Europhysics Letters), $86(6), 68001$.

Rahayu, R. N., \& Idhani, D. (2019). Khizanah al-Hikmah: Jurnal Ilmu Perpustakaan, Informasi, dan Kearsipan (analisis bibliometrika pada terbitan tahun 2013-2018). Khizanah Al-Hikmah: Jurnal Ilmu Perpustakaan, Informasi, Dan Kearsipan, 7(1), 82-91.

Rahayu, R. N., \& Tupan, T. (2020). Studi Bibliometrik Artikel Jurnal Perpustakaan Pertanian Periode $2013-$ 2017. Jurnal Perpustakaan Pertanian, 27(2), 44-50. http://dx.doi.org/10.21082/jpp.v27n2.2018.p44-50

Royani, Y., \& Idhani, D. (2019). Analisis Bibliometrik Jurnal Marine Research in Indonesia. Media Pustakawan, 25(4), 60-65. https://doi.org/10.37014/medpus.v25i4.200

Saleh, A. R., \& Sumarni, E. (2019). Studi bibliometrik pada Jurnal Standardisasi pasca terakreditasi (20112015). VISI PUSTAKA: Buletin Jaringan Informasi Antar Perpustakaan, 18(3), 231-240. https://doi.org/10.37014/visi\%20pustaka.v18i3.133

Sandulescu, V., \& Chiru, M. (2016). Predicting the future relevance of research institutions-The winning solution of the KDD Cup 2016. ArXiv Preprint ArXiv:1609.02728.

Subramanyam, K. (1983). Bibliometric studies of research collaboration: A review. Journal of Information Science, 6(1), 33-38. https://doi.org/10.1177/016555158300600105

van Eck, N. J., \& Waltman, L. (2010). Software survey: VOSviewer, a computer program for bibliometric mapping. Scientometrics, 84(2), 523-538. https://doi.org/10.1007/s11192-009-0146-3

Verma, S., \& Gustafsson, A. (2020). Investigating the emerging COVID-19 research trends in the field of business and management: A bibliometric analysis approach. Journal of Business Research, 118, 253261. https://doi.org/10.1016/j.jbusres.2020.06.057 